\title{
Intellectual Capital and Financial Performance of English Football Club
}

\author{
Bima Cinintya Pratama ${ }^{1}$, Maulida Nurul Innayah ${ }^{2}$, Prita Esita ${ }^{3}$, Dwi Winarni ${ }^{4}$, Anggi \\ Setyawan $^{5}$ \\ \{pratamabima@gmail.com¹, nanamaulida@gmail.com², pritaesita1@gmail.com³
}

Faculty of Economics and Business, Universitas Muhammadiyah Purwokerto, Indonesia ${ }^{12345}$

\begin{abstract}
This study test the components of IC effect and IC itself as a whole towards Return on Assets as a measure of performance of football clubs in the UK. The samples of this study are 42 football clubs and generated as many as 126 data. Hypothesis testing results showed that intellectual capital components (human capital, structural capital, and capital employed) simultaneously affects financial performance. While, human capital has a positive effect on ROA, structural capital has a negative effect on ROA, and capital employed has no effect on ROA. The results of this study implies that football firms must maximize their IC resources to the fullest, especially in terms of human resources.
\end{abstract}

Keywords: intellectual capital, financial performance, structural capital, human capital, capital employed

\section{Introduction}

"Football is not just a game". A sentence that may be a bit strange to be heard by some people who are not too enthusiastic about football. In the past, football was only regarded as an ordinary game containing 22 players plus 3 referees and aimed only at sports, but in the last one to two decades football developed into a new business that had exceptionally high profit prospects [11].

The most famous sport in the whole world, especially in England, is football. In the English football industry, players with high salaries will be easily found, because the English league is the home to high-paying players. This is what makes the English League can break the transfer record of a player and this also affects the rights of television broadcasters who are willing to spend large amounts of sponsorship funding. But when an evaluation is conducted, the English league can experience bankruptcy because the Premier League has a return on assets (ROA) of minus $5 \%$ due to inequality that occurs in the process of transfer in and out of players and the high salaries of their players [17].

Amir and Livne [1] found that human resources are one of the revenue drivers for football clubs. The success of players and coaches will have a direct impact on the commitment of fans and the financial performance of a club. People who play as managers, players, technical staff are the main components in the football industry and the accounting methods applied are also not enough to measure the hidden value in football [25].

World-famous players like Lionel Messi, Cristiano Ronaldo, Mohammad Salah, Zlatan Ibrahimovic and Sergio Kun Aguero had a big impact on the football club's performance. When a club has players like them, sales of merchandise, match tickets will always be high. 
From this phenomenon the elements of Intellectual Capital (mainly Human Capital) have a high impact on the performance of football clubs. Human capital itself is a major component of intellectual capital according to Moon and Kym [14].

Sullivan [27] described IC as information that if utilize will could lead to profit. Demirkol [7] explained that information about how managing a company and carrying out its duties are reflected in IC. Intellectual capital is a decisive component for the company's values and the value of know how that triggered by performance (Petty and Guthrie, 2000). Sangkala [24] explained that IC is material in the form of information, innovation, intellectual, experience, and knowledge. Those could be managed in order to create value added and provide advantage which is competitive.

Pulic [21] [22] created an IC measurement (Value Added Intellectual Coefficient or VAIC) which could measure the value added and competitive advantage. It is a combination of components that measure Human Capital, Structural Capital, and Physical Capital.

Some past research from Pratama [18], Pratama and Wibowo [19], Pratama, et al. [20], Yasar et al. [28], and Muhanik \& Septiarini [15] showed that IC had a positive effect towards performance. Meanwhile research from Andriana [2], Kuryanto [13], and Firer \& Williams [8] showed that intellectual capital has no effect towards performance. Therefore, from the inconclusive conlusion from previous research and the lack of research about IC in football industry, it is interesting to examines those relationship between IC and its components towards performances.

\section{Literature}

\subsection{Resource-based Theory (RBT)}

RBT serves as the main driver in defining competitive advantage and outcome that are resulted from company's performance [5]. Kozlenkova et al. [12] clarified that this hypothesis depends on two starting suppositions about organization assets and a clarification of how these assets can make competitive advantages and why a few organizations can be reliably superior to others. First, in the same industry, companies have different resources [17]. This statement about the assorted variety of assets shows that a few organizations have assets with better and unique ability than in finishing exercises than other [17]. Second, difficulties in exchanging resources between companies make the difference in the resources of each company will still be present, the diversity of these resources will affect the profits that occur every time [12].

The way to assess the potential of resources that can create sustainable competitive advantage is based on 4 characteristics: valuable, rare, cannot be replicated perfectly, and organizations that are commonly abbreviated as VRIO [12]. The following are the characteristics of VRIO (Valuable, Rare, Imperfectly imitable, Organizations).

\subsection{The Effect of IC on Performance}

According to resource based theory (RBT), IC is a resource that serves the core function in creating value and competitive advantage of the company [18]. With the use of IC, it is expected to increase sales and use company resources efficiently and economically that can make an increase in company profits. IC cannot stand alone without its components [22]. Therefore, it is predicted that the IC components simultaneously contribute to each other in improving performance. 
Based on previous research from Pratama [18], Pratama and Wibowo [19], Pratama, et al. [20], Yasar et al. [28], and Muhanik \& Septiarini [15] have known that IC improve performance, therefore:

\section{H1: Intellectual Capital components have simultaneous effect towards firm performance.}

\subsection{The Effect of HC on Performance}

RBT explained that the organization's worth and competitive advantage was made from IC [4]. RBT also tell that the organization's endeavors to look after valuable, scarce and indispensable assets are firmly identified with the formation of competitive advantage [4]. HC (Human capital) is part of IC [22]. Human capital is significant in light of the fact that there is a blend of abilities, talents, knowledge, expertise, and insight that lead to performance [23].

Research by Gozali and Hatane [9], Hamidah [10], and Muhanik \& Septiarini [15] showed that Human Capital lead to improve of performance.

\section{H2: Human Capital has positive effect towards firm performance.}

\subsection{The Effect of SC on Performance}

RBT clarified that IC is the primary concern that must exist in making value and competitive advantage [4].

As indicated by RBT, the arrangement of competitive advantage is firmly identified with the organization's endeavors to maintain valuable, rareand indispensable asset resources and utilize these assets effectively [4]. Structural capital (SC) is important for IC [22]. SC is made from the organization's cycles and values, which reflect the focal point of the organization both internal and external, in addition to the turn of events and reestablishment of qualities for the future [3]. Research by Chen et al. [6] and Gozali and Hatane [9] showed that SC lead to performance.

\section{H3: Structural Capital has positive effect towards firm performance.}

\subsection{The Effect of CE or PC on Performance}

RBT characterizes that the primary aspect in the making of value and competitive advantage is IC [4]. From the RBT viewpoint that the production of manageable competitive advantage is firmly identified with the organization's endeavors to keep up important asset resources and cycles when running these assets [4]. Capital employed or physical capital (CE or PC) is essential for IC [22]. Study from Pulic [21] expect that one unit of CE produces a more noteworthy profit for an organization than another organization, at that point the organization utilizes its CE. Research by Chen [6] and Hamidah [10] found that CE lead to performance.

H4: Capital Employed has positive effect towards firm performance.

\section{Methods}


English football clubs that played in the Premier League and championship division in the $2018 / 2019$ season was the population and sample in this study by using purposive sampling technique. Based on the sample criteria that have been selected in this study, a total of 42 football clubs are obtained each year where the period used in this study is the 2013/2014 2015/2016 or 2014-2016 season. So that the total overall sample used was 126.

\subsection{Variables}

a) Dependent Variable (Y)

Financial Performance

RoA was used to proxied performance following the research by Chen [6]. ROA was measured using the following formula:

$$
\text { ROA }=\frac{\text { Profit before tax }}{\text { Total asset }}
$$

\section{b) Independent Variable (X)}

$\boldsymbol{V A I C}$

VAIC takes a relatively simple quantitative approach to measure ICs and their components [21].

Where:

$$
\mathbf{V A}=\mathbf{O P}+\mathbf{E C}+\mathrm{D}+\mathrm{A}
$$

VA is a calculation by adding operational income (OP), employee costs (EC),

depreciation (D) and amortization (A)

$\mathrm{HC} \quad=$ total wages and salaries

SC $\quad=$ VA- HC; structural capital

$\mathrm{CE} \quad=$ net assets

\section{Human Capital (HCE)}

HCE represents the efficiency of human resources to apply skills and expertise efficiently

[21] [22], calculated by:

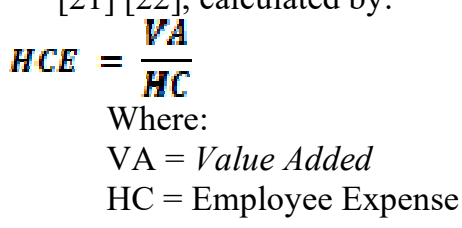

\section{Structural Capital (SCE)}

SCE represents the efficiency of structural capital and relational capital [21] [22], calculated by:

Where:

$$
S C E=\frac{S C}{V A}
$$

$\mathrm{SC}=\mathrm{VA}-\mathrm{HC}$

$\mathrm{VA}=$ Value Added

\section{Capital Employed (CEE)}

Capital Employed represents efficient use of physical and financial capital [21] [22], calculated by: 
$C E E=\frac{V A}{C E}$

$\mathrm{VA}=$ Value Added

$\mathrm{CE}=$ Capital Employee

\section{Results And Discussion}

a. Descriptive Statistics

Data analysis with descriptive statistics provides an overview of data. The results are as follows:

Table 1. Descriptive Statistics

\begin{tabular}{llllll}
\hline & $\mathrm{N}$ & Minimum & Maximum & Mean & Std. Deviation \\
\hline HCE & 126 & $-0,0023$ & 5,2769 & 1,717914 & 0,7781753 \\
SCE & 126 & $-1,71$ & 441,67 & 3,7679 & 39,32634 \\
CEE & 126 & $-63,52$ & 48,40 & 0,7151 & 9,10837 \\
ROA & 126 & $-2,15$ & 5,13 & $-0,1849$ & 0,70474 \\
\hline
\end{tabular}

Variables: HCE: Human Capital; SCE: Structural Capital ; CEE: Capital Employed ; ROA: Return on Assets

Table 1 showed that the ROA of 126 football club samples has a minimum value of -2.15 obtained from Bristol City in 2014 while a maximum value of 5.13 was obtained from Sheffield United in 2014. Meanwhile, human capital (HCE) of 126 samples clubs have a minimum value of -0.0023 obtained from AFC Bournemouth in 2015 and a maximum value of 5.2769 obtained from Sheffield United in 2014. Furthermore, structural capital (SCE) of 126 club samples has a minimum value of -1.71 obtained from Bristol City in 2014 while a maximum value of 441.67 was obtained from AFC Bournemouth in 2015. Then, capital employed (CEE) of 110 club samples had a minimum value of -63.52 obtained from Sheffield Wednesday in 2014 while a maximum value of 48.40 was obtained from Birmingham City in 2014.

\section{b. Coefficient of Determination Test $\left(\mathbf{R}^{2}\right)$}

The size or ability if model to explain dependent variable is showed by coefficient of determination (R2), which can be seen in the table below:

Table 2. Coefficient of Determination Test

\begin{tabular}{lllll} 
Model & $\mathrm{R}$ & $\mathrm{R}$ Square & Adjusted R Square & Std. Error of the Estimate \\
\hline 1 & $0,732^{\mathrm{a}}$ & 0,535 & 0,522 & 0,19392 \\
\hline a. Predictors: (Constant), & CEE, SCE, HCE
\end{tabular}

Based on table 2 the coefficient of determination obtained Adjusted R Square value of 0.522 means that $52.2 \%$ ROA variable can be explained by HCE, SCE and CEE variables while the remaining $47.8 \%$ is explained by variables outside model. 


\section{c. Simultaneous Test (F-Test)}

To know whether all independent variables included in the model have a simultaneous effect on the dependent variable is using $F$ test which can be seen below:

Table 3. F-Test Results

\begin{tabular}{lll}
\hline Model & F & Sig. \\
\hline 1 & 40,730 & $0,000^{\mathrm{b}}$ \\
\hline
\end{tabular}

Based on table 3 , the sig. value of $\mathrm{F}$ test is 0.000 means that the variable of IC components have a simultaneous effect on performance.

\section{d. Multiple Regression Analysis}

Table 4. Multiple Linear Regression Results

\begin{tabular}{|c|c|c|c|c|c|c|}
\hline \multirow{2}{*}{\multicolumn{2}{|c|}{ Model }} & \multicolumn{2}{|c|}{ Unstandardized Coefficients } & \multirow{2}{*}{$\begin{array}{l}\text { Standardized } \\
\text { Coefficients } \\
\text { Beta } \\
\end{array}$} & \multirow[b]{2}{*}{$\mathrm{T}$} & \multirow[b]{2}{*}{ Sig. } \\
\hline & & $\mathrm{B}$ & Std. Error & & & \\
\hline \multirow[t]{4}{*}{1} & $\mathrm{C}$ & $-0,563$ & 0,054 & & $-10,511$ & 0,000 \\
\hline & $\mathrm{HCE}$ & 0,265 & 0,028 & 0,643 & 9,357 & 0,000 \\
\hline & SCE & $-0,001$ & 0,000 & $-0,218$ & $-3,191$ & 0,002 \\
\hline & CEE & 0,001 & 0,002 & 0,032 & 0,474 & 0,637 \\
\hline
\end{tabular}

Dependent Variable: ROA

The regression equation that can be made based on the results of the regression coefficient is:

$$
\text { ROA }=-0,563+0,265 \mathrm{HCE}-0,001 \mathrm{SCE}+0,001 \mathrm{CEE}+\mathrm{e}
$$

\section{Discussion}

\subsection{Hypothesis 1 Test Results}

The results of the $\mathrm{F}$ test (Table 3 ) showed that the $\mathrm{F}$ value is 40.730 which is greater than the $\mathrm{F}$ table 2.69. The value statistically showed a significant result of $0.000<0.05$ means that the independent variables (HCE, SCE, CEE or the components of Intellectual Capital) has a simultaneous effect towards the dependent variables. This showed that simultaneously Intellectual capital components, namely human capital (HCE), structural capital (SCE) and employed capital (CEE) have a simultaneous effect financial performance (ROA). The results of this study are in line with the research of Pratama [18], Pratama and Wibowo [19], Pratama, et al. [20], Yasar et al. [28], and Muhanik \& Septiarini [15] which found that intellectual capital has a positive effect on firm performance. The results are in line with predictions according to the grand theory of RBT. Pratama [18] clarifies that in accordance with RBT, organizations that have assets that can't be imitated by contenders will get the advantage to contend in the market and make ideal performance. 


\subsection{Hypothesis 2 Test Results}

The t-test results showed that human capital variable (HCE) have a positive effect on performance. The results of this study are align with research from Chen [6], Hamidah [10] and Rahim et al. [23]. This is in line with theoretical predictions. Kozlenkova et al. [12] clarified that there are two introductory suppositions about assets organization why these assets can make upper hands that can improve organization execution and can reliably be superior to different organizations. The expert administration and use of human capital means to empower HR to work adequately, proficiently and profitably. This is proven if from a football club that has a talented player and has a brilliant achievement, the income from the club will rise, namely by selling marchandise, jersey and stadium tickets by many fans from the club. This is what makes a soccer player can improve the financial performance of the soccer club.

\subsection{Hypothesis 3 Test Results}

The t-test results showed that structural capital variable (SCE) has a negative effect on performance. The results of this study are consistent with the results of research by Muhanik \& Septiarini [15], and Andriana [2]. Muhanik \& Septiarini [15] explained that if a company has structural capital (planning, organizing, strategy, procedures, systems and other assets) but it is not maximized, it will not increase the company's profit and it will be waste. According to resource-based theory proposed by Kozlenkova et al. [12] likewise clarified that assets must have VRIO qualities in order to lead to improve performance, maybe the SC does not meet VRIO characteristics, so it does not improve performance.

\subsection{Hypothesis 4 Test Results}

The t-test results showed that capital employed (CEE) has no effect on financial performance (ROA). The results of this study are consistent with the results of research by Muhanik \& Septiarini [15], Andriana [2] and Suhendah [26]. Suhendah [26] clarified that physical resources in knowledge based organizations are not the principle resources that can improve organization performance. According to resource-based theory proposed by Kozlenkova et al. [12] likewise clarified that assets must have VRIO qualities in order to lead to improve performance, maybe the CE does not meet VRIO characteristics, so it does not improve performance.

\section{Conclusions}

This study examines the effects of intellectual capital using VAIC towards Return on Assets (ROA) of football clubs in the UK. From the results of hypothesis testing using multiple regression tests it can be concluded that IC component, namely HCE, SCE and CEE simultaneously affect financial performance (ROA), Human Capital has a positive effect on financial performance (ROA), Structural Capital has a negative effect on financial performance (ROA), Physical Capital has no effect on financial performance (ROA). The results of this study implies that football firms must maximize their IC resources to the fullest, especially in terms of human resources. 
Based on the findings above, further research should conduct IC testing on other dependent variables other than using Firm Performance (ROA), for example by using the dependent variable of Firm Value (MV). Further research is also expected to increase the number of samples by expanding the area of the country not only in the UK such as Spain, Germany, Italy and France or countries with a large football industry.

\section{References}

[1] Amir, Eli, and Gilad Livne. (2001). Accounting for Human Capital when Labor Mobility is Restricted. London Business School.

[2] Andriana, D. (2014). Pengaruh Intellectual Capital Terhadap Kinerja Keuangan Perusahaan. Jurnal Riset Akuntansi dan Keuangan, 2 (1), 2014, 251-260.

[3] Astuti. 2005. Hubungan Intellectual Capital dan Business Perfomance. Jurnal Maksi, Januari, Vol. 5, halaman 34-58.

[4] Barney, J. B. 1991. Firm resources and sustained competitive advantage. Journal of Manage-ment, 17 (1), 99-120.

[5] Barney, J. B., D. Ketchen, and M. Wright. 2011. The future of resource based theory: Revi-talization or decline?. Journal of Manage-ment, 37 (5), 1299-1315.

[6] Chen, M., Cheng, S., \& Hwang, Y. (2005). An Empirical Investigation of The Relations between Intellectual Capital and Firm's Market Value and Financial Performance. Journal of Intellectual Capital, 6(2), 159- 176.

[7] Demirkol. I. (2007), Entelektüel sermayenin firma değerine etkisi ve IMKB'de sektörel uygulamalart- Impact of intellectual capital on firm value and stock sectoral applications. SPK. Ankara.

[8] Firer, S dan Williams, M. (2003). Intellectual Capital and Traditional Measures of Corporate Performance. Journal of Intellectual Capital. 4(3), 348-360.

[9] Gozali, A., dan Hatane, S. E. 2014. Pengaruh Intellectual Capital Terhadap Kinerja Keuangan dan Nilai Perusahaan Khususnya Di Industri Keuangan dan Industri Pertambangan Yang Terdaftar Di Bursa Efek Indonesia Tahun 2008 - 2012. Business Accounting Review, Vol. 2, No.2, Juli 2014:208-21.

[10] Hamidah. (2014). Pengaruh Intellectual Capital Terhadap Kinerja Keuangan Pada Bank Go Public Yang Terdaftar Di Bursa Efek Indonesia Tahun 2009-2012. Jurnal Riset Manajemen Sains Indonesia (Jrmsi). Vol. 5

[11] Haryoprasetyo, R., dan Kiswara, E (2013). Analisis Atas Kinerja Finansial Klub Sepakbola Profesional : Studi Kasus Pada Manchester United PLC. Diponegoro Journal Of Accounting, Volume 2, Nomor 3, Tahun 2013, Halaman 1-8.

[12] Kozlenkova, I. V., S. A. Samaha, and R. W. Palmatier. 2014. Resource-based theory in marketing. Journal of the Academy of Marketing Science, 42 (1), 1-21.

[13] Kuryanto, B dan Syafruddin, M. (2008). Pengaruh Modal Intelektual terhadap Kinerja Keuangan Perusahaan. Simposium Nasional Akuntansi XI. Pontianak, 1-30.

[14] Moon. J. Y., Kym and H. G. (2006), A model for the value of intellectual capital, Canadian Journal of Administrative Sciences, Vol.23, pp.253-269.

[15] Muhanik, V. Dan Septiarini, D.F. (2017). Pengaruh Intellectual Capital Terrhadap Return On Asset Pada Bank Umum Syariah di Indonesia Periode Q1.2013 - Q4.20141). Jurnal Ekonomi Syariah Teori dan Terapan Vol. 4 No. 1 Januari 2017 : 1-13.

[16] Petty, R. \& J. Guthrie. 2000. Intellectual Capital Literature Review: Measurement, Report-ing, and Management. Journal of Intellectual Capital, 1(1). pp. 155-176.

[17] Prasatya 2015: Keganjilan Industri Sepakbola Inggris. (2015). Di akses 22 Januari, 2019, from Pandit $\quad$ Football Web site 
http://www.panditfootball.com/cerita/173295/RPA/150310/keganjilan-industrisepakbola-inggris

[18] Pratama, B. C. 2016. The Impact of Intellectual Capital of Indonesian's High-Tech Company on Firm's Financial and Market Performance. International Journal of Academic Research in Accounting, Finance and Management Sciences, Vol. 6, No. 4, October 2016, pp. 73-81. E-ISSN: 2225-8329, P-ISSN: 2308-0337.

[19] Pratama, B. C., and Wibowo, H. 2017. Family Ownership and the Entrenchment Effect on Intellectual Capital Utilization: A Study of High-Technology Companies in Indonesia Dealing with the ASEAN Economic Community (AEC). Jurnal Akuntansi dan Investasi, Vol. 18 No. 2, pp. 222-230.

[20] Pratama, B. C., H. Wibowo, and M. N. Innayah. 2019. Intellectual Capital and Firm Performance in ASEAN: The Role of Research and Development. Journal of Accounting and Investment, Vol. 20 No. 3, pp. 236-250.

[21] Pulic, A. (2000). VAIC: an accounting tool for IC management. International Journal of Technology Management. Vol. 20 (5-8): 702-714.

[22] Pulic, A. (2004). Intellectual capital - does it create or destroy value?. Measuring Business Excellence. Vol. 8 (1): 62-68.

[23] Rahim, A., Atan, R. and Kamaluddin, A. 2017. Human Capital Efficiency and Firm Perfomance: An Empirical Study On Malaysia Technology Industry. SHS Web of Conferences 36, 00026 (2017) DOI: 10.1051/shsconf/2017360002 2016 ICGA.

[24] Sangkala. 2006. Intellectual Capital Management: Strategi Baru Membangun Daya Saing Perusahaan. Jakarta: Yapensi.

[25] Shareef. F. and Davey. H. (2005), Accounting for intellectual capital: Evidence from listed English football clubs, The Journal of Applied Accounting Research, Vol.7, pp.78-116.

[26] Suhendah. (2012). Pengaruh Intellectual Capital Terhadap Profitabilitas, Produktivitas dan Penilaian Pasar Pada Perusahaan yang Go Public di Indonesia Pada Tahun 2005 2007. Jurnal dan Prosiding SNA - Simposium Nasional Akuntansi. Vol. 15.

[27] Sullivan P. H. (1999), Profiting from intellectual capital, Journal of Knowledge Management, Vol.3, pp.132-142.

[28] Yasar, N. N., Isik, M., and Calisir, F. (2015). Intellectual capital efficiency: the case of football clubs. Procedia - Social and Behavioral Sciences 207 ( 2015 ) $354-362$. 